\title{
Sir William Collins CBE
}

Billy Collins, who died last September, served on the FPS Council from 1970 until he retired by rotation in June 1976 . He was above all a publisher, Chairman of the thriving and influential firm whose name he bore, but the cause of wildlife conservation was very near his heart, and as a publisher he was able to (and did) promote its aims with astonishing success. By popularising wildlife and the need to conserve it, especially through such bestsellers as the Elsa books, he did as much as any of his contemporaries to forward the cause, and made his firm the outstanding one in the wildlife field. His enthusiasm was a joy to experience, and unlike so many other enthusiasms it was backed by great pertinacity, business sense and drive. One of his major monuments is the New Naturalist series, which has attained its diamond jubilee - the latest, on British birds of prey, was no. 60. It was appropriate that Billy should have died in harness, on the morrow of the Frankfurt Book Fair, vigorous and hard at it to the end.

R.F.

\section{Tom Harrisson DSO OBE}

Tom Harrisson, who was killed last year with his wife Christine in a road accident in Thailand, was one of the buccaneers of wildlife conservation, as of life itself. Such men are worth their weight in turtles and tamaraws, to mention two of his main conservation successes. His interest in wildlife began early. While still at school at Harrow, Middlesex, he wrote, jointly with his brother W.R.D. Harrisson and others, an account of the birds of the district. His interest in and connections with South-east Asia began as a member of the Oxford University Expedition to Borneo in 1932. After an interlude in Britain in which he founded the unique social research institution called Mass Observation, he returned to Borneo as a major in the British Army in 1944.

In 1947 he became Curator of the old established Sarawak Museum and later assisted in the foundation of the Brunei Museum. Here, alongside his manifold anthropological and archaeological activities, he found time to study the wildlife, notably the edible swiftlets and other birds and the green turtles. Even after his retirement in 1969 he continued his involvement both as a consultant who visited Brunei annually and as a professor in Cornell University's South-east Asia Programme. Almost his first publication after his appointment at Kuching was a paper on the large mammals of Borneo in the Malayan Nature Journal in 1949, followed by another in Oryx in 1955 on 'Borneo Fauna Anxieties'.

It was the green turtle rookeries on the islands of Satang and TalangTalang, off Sarawak, that first engaged his practical activity for wildlife conservation. From about 1948 he developed a pioneer turtle conservation scheme, the first of its kind, in which all eggs were collected under supervision, a proportion of them re-buried in sheltered areas for hatching and the babies raised in tanks until they could be returned to the sea, away from the predators close to the shore, the whole operation being paid for by marketing other eggs. This early turtle work was important in several ways: it gave control of the islands and produced exact records of three breeding beaches; the tagging showed that Chelonia mydas, the green turtle, only returns to lay every three to five years, and that individuals come to the same beach every time, up to five 